\title{
Sistem Kendali Pintu Gerbang dengan Menggunakan Bluetooth Android
}

\author{
Ariyono Setiawan \\ Yuyun Suprapto \\ Totok Warsito \\ Akademi Teknik dan Keselamatan Penerbangan Surabaya \\ Jl.Jemur Andayani 1/73 Wonocolo Surabaya 60236 \\ Telp.(031)841087, Fax.(031)8490005 \\ E-mail: rmaryo4u@gmail.com
}

\begin{abstract}
There are less constraints responded a remote device that is controlled by conventional control (still using infrared as a transmission medium). This led the creation of new control system which utilizes Bluetooth as a medium of communication. The working principle of this control system design is to use a cell phone as a microcontroller as remotnya and data processing and control. The design is driven by a series of minimum ATMega system with IC 16 as a processor and controller.
\end{abstract}

Key Words: gate control system, bluetooth, android

\section{Pendahuluan}

Saat ini telah banyak digunakan peralatan elektronik yang dapat dikendalikan dengan menggunakan remote control yang menggunakan infra merah (infra red) sebagai media komunikasinya. Namun penggunaan infra merah memiliki beberapa kelemahan yaitu komunikasi harus berlangsung secara segaris lurus (line of sight) dan dari jarak yang sangat dekat. Diperlukan sebuah cara yang lain untuk mengatasi keterbatasan yang ada tersebut. Oleh karena itu hadirlah Bluetooth. Bluetooth adalah sebuah cara yang berbeda untuk menghubungkan peralatan elektronik pada jarak yang relatif dekat, yang dapat dianggap sebagai pengganti kabel. Namun teknologi Bluetooth menawarkan lebih dari sekedar pengganti kabel. Bluetooth adalah sebuah teknologi frekuensi radio yang menggunakan pita frekuensi Industri-SainsMedis (ISM) 2,4 GHz.

Dengan aplikasi gratis pada handphone android, kita dapat membuat handphone android tersebut sebagai remote control. Hal ini disebabkan handphone android banyak digunakan di Indonesia, maka penulis bermaksud membuat rancangan dalam sebuah tugas akhir yang memiliki judul "Sistem Kendali Pintu Gerbang Dengan Menggunakan Bluetooth Android“. Dengan tujuan dapat menambah fungsi dari pada handphone agar bisa digunakan untuk mengendalikan sebuah peralatan. Dari latar belakang masalah yang telah penulis kemukakan, selama ini sistem kendali peralatan elektronik (remote control) masih menggunakan teknologi infra merah dan remote control yang hanya cocok dengan alat - alat tertentu, dan hal itu dianggap kurang effisien dan memiliki kelemahan sebagai sebuah sistem kendali peralatan elektronik (remot kontrol), untuk itu perlu di adakan cara lain (alternatif) pada sistem kendali peralatan elektronik (remote control) tersebut dengan menggunakan Bluetooth sebagai media komunikasinya dan handphone sebagai system kendalinya. Penulis mengidentifikasi beberapa masalah yang ada antara lain sebagai berikut :

1. Sistem kendali (remote control) masih menggunakan teknologi infra merah yang mengharuskan pengguna agar melakukan komunikasi dalam satu garis lurus (line of sight).

2. Satu sistem kendali (remote control) untuk satu alat elektronik.

3. Sistem kendali (remote control) perlu diadakan pengembangan seiring dengan perkembangan ilmu pengetahuan dan teknologi.

Rumusan masalah dalam penelitian ini yaitu 
1. Apa yang menjadi kelebihan sistem kendali (remote control) pintu gerbang dengan handphone melalui Bluetooth yang akan dirancang oleh penulis

2. Bagaimana cara kerja sistem kendali (remote control) pintu gerbang menggunakan handphone melalui Bluetooth?

\section{Tinjauan Teori \\ Resistor}

Resistor seperti pada gambar 1 dan gambar 2 adalah komponen dasar elektronika yang digunakan untuk membatasi jumlah arus yang mengalir dalam satu rangkaian. Resistor bersifat resistif dan umumnya terbuat dari bahan karbon. Resistor dapat digolongkan menjadi dua macam, yaitu resistor tetap dan resistor variabel. Resistor tetap nilainya tidak dapat diubah sedangkan resistor variabel dapat diubahubah nilainya sesuai dengan rancangan yang kita kehendaki. Jenis dari resistor tetap adalah resistor logam dan resistor arang, sedangkan resistor variabel adalah resistor arang yang merupakan potensiometer dan resistor kawat logam.

Gambar 1 : Resistor

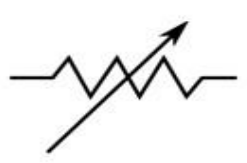

Gambar 2 : Bentuk fisik resistor

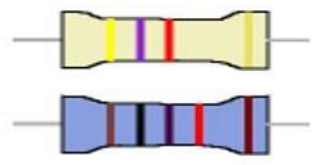

Tabel 1 : Nilai hambatan dari tiap warna

\begin{tabular}{|c|c|c|c|}
\hline Warna & Nilai & faktor & Toleransi \\
\hline Hitam & 0 & 1 & \\
\hline Coklat & 1 & 10 & $1 \%$ \\
\hline Merah & 2 & 100 & $2 \%$ \\
\hline Jingga & 3 & 1.000 & \\
\hline Kuning & 4 & 10.000 & \\
\hline Hijau & 5 & 100.000 & \\
\hline Biru & 6 & $10^{6}$ & \\
\hline Violet & 7 & $10^{7}$ & \\
\hline Abu- & 8 & $10^{8}$ & \\
\hline Putih & 9 & $10^{9}$ & \\
\hline Emas & - & 0.1 & $5 \%$ \\
\hline Perak & - & 0.01 & $10 \%$ \\
\hline Tanpa & - & - & $20 \%$ \\
\hline
\end{tabular}

Spesifikasi lain yang perlu diperhatikan dalam resitor pada suatu rancangan selain besar resistansi adalah besar watt-nya. Karena resistor bekerja dengan dialiri arus listrik, maka akan terjadi dis ipasi daya berupa panas sebesar $\mathrm{W}=\mathrm{I}^{2} \cdot \mathrm{R}$ watt. Semakin besar ukuran fisik suatu resistor bisa menunjukkan semakin besar kemampuan disipasi daya resistor tersebut. Untuk memperbesar nilai tahanan pada resistor yaitu dengan merangkai beberapa resistor secara seri, sedangkan untuk memperkecil nilai tahanan pada resistor, yaitu dengan merangkai beberapa resistor secara paralel.

Resistor merupakan komponen pasif yang bersifat menghambat. Selain fungsi menghambat, resistor juga memiliki fungsi pembagi tegangan. Rangkaian pembagi tegangan yang disusun dengan resistor terlihat seperti gambar dibawah ini.

Gambar 3: Rangkaian pembagi tegangan

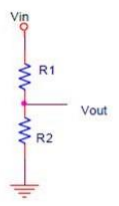

\section{Kapasitor}

Kapasitor seperti pada gambar 2.6 dan gambar 2.7 atau sering disebut sebagai kondensator adalah suatu alat yang dapat menyimpan energi di dalam medan listrik, dengan cara mengumpulkan ketidakseimbangan internal dari muatan listrik. Kapasitor memiliki satuan yang disebut Farad dari nama Michael Faraday. Kapasitor juga dikenal sebagai kondensator, namun kata kondensator masih dipakai hingga saat ini. Pertama disebut oleh Alessandro Volta seorang ilmuwan Italia pada tahun 1782 (dari 
bahasa Itali condensatore ), berkenaan dengan kemampuan alat untuk menyimpan suatu muatan listrik yang tinggi dibanding komponen lainnya. Satuan kapasitor disebut Farad (F). Satu Farad $=9 \times 1011 \mathrm{~cm}^{2}$ yang artinya luas permukaan kepingan tersebut.

Struktur sebuah kapasitor terbuat dari 2 buah plat metal yang dipisahkan oleh suatu bahan die lektrik. Bahan-bahan dielektrik yang umum dikenal misalnya udara vakum, keramik, gelas dan lain-lain. Jika kedua ujung plat metal diberi tegangan listrik, maka muatan-muatan positif akan mengumpul pada salah satu kaki (elektroda) metalnya dan pada saat yang sama muatan-muatan negatif terkumpul pada ujung metal yang satu lagi. Muatan positif tidak dapat mengalir menuju ujung kutub negatif dan sebaliknya muatan negatif tidak bisa menuju ke ujung kutub positif, karena terpisah oleh bahan dielektrik yang nonkonduktif. Muatan elektrik ini tersimpan selama tidak ada konduksi pada ujung-ujung kakinya. Di alam bebas, phenomena kapasitor ini terjadi pada saat terkumpulnya muatan-muatan positif dan negatif di awan.

Gambar 4 : Simbol kapasitor

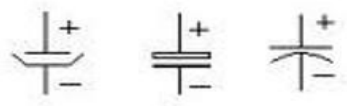

Berdasarkan kegunaannya kapasitor dibagi menjadi :

1. Kapasitor tetap (nilai kapasitasnya tetap tidak dapat diubah)

2. Kapasitor elektrolit (Electrolit Condenser $=$ Elco)

3. Kapasitor variabel (nilai kapasitasnya dapat diubah-ubah)

Pada kapasitor yang berukuran besar, nilai kapasitansi umumnya ditulis dengan angka yang jelas. Lengkap dengan nilai tegangan maksimum dan polaritasnya. Kapasitor yang ukuran fisiknya kecil biasanya hanya bertuliskan 2 (dua) atau 3 (tiga) angka saja.

\section{Diode}

Diode yang terlihat seperti gambar 5 dan 6 adalah komponen aktif bersaluran dua (diode termionik mungkin memiliki saluran ketiga sebagai pemanas). Dioda mempunyai dua elektroda aktif dimana isyarat listrik dapat mengalir, dan kebanyakan dioda digunakan karena karakteristik satu arah yang dimilikinya. Dioda varikap (Variable Capacitor / kondensator variabel) digunakan sebagai kondensator terkendali tegangan.

Sifat kesearahan yang dimiliki sebagian besar jenis dioda seringkali disebut karakteristik menyearahkan. Fungsi paling umum dari dioda adalah untuk memperbolehkan arus listrik mengalir dalam suatu arah (disebut kondisi panjar maju) dan untuk menahan arus dari arah sebaliknya (disebut kondisi panjar mundur). Karenanya, dioda dapat dianggap sebagai versi elektronik dari katip pada transmisi cairan.

Gambar 5: Bentuk fisik diode dan simbol

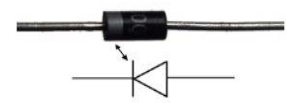

Dioda sebenarnya tidak menunjukkan kesearahan hidup-mati yang sempurna (benar-benar menghantar saat panjar maju dan menyumbat pada panjar mundur), tetapi mempunyai karakteristik listrik tegangan-arus taklinier kompleks yang bergantung pada teknologi yang digunakan dan kondisi penggunaan. Beberapa jenis dioda juga mempunyai fungsi yang tidak ditujukan untuk penggunaan penyearahan. 
Gambar 6: Struktur Dan Simbol Dioda

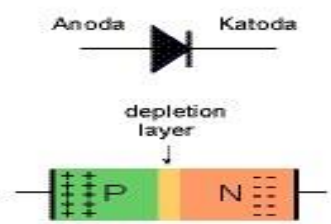

Dioda memiliki fungsi yang unik yaitu hanya dapat mengalirkan arus satu arah saja. Struktur dioda tidak lain adalah sambungan semikonduktor P dan N. Satu sisi adalah semikonduktor dengan tipe P dan satu sisinya yang lain adalah tipe N. Dengan struktur demikian arus hanya akan dapat mengalir dari sisi P menuju sisi $\mathrm{N}$.

Gambar ilustrasi di atas menunjukkan sambungan PN dengan sedikit porsi kecil yang disebut lapisan deplesi (depletion layer), dimana terdapat keseimbangan hole dan elektron. Seperti yang sudah diketahui, pada sisi $\mathrm{P}$ banyak terbentuk hole-hole yang siap menerima elektron sedangkan di sisi $\mathrm{N}$ banyak terdapat elektron-elektron yang siap untuk bebas merdeka. Lalu jika diberi bias positif, dengan arti kata memberi tegangan potensial sisi $\mathrm{P}$ lebih besar dari sisi $\mathrm{N}$, maka elektron dari sisi $\mathrm{N}$ dengan serta merta akan tergerak untuk mengisi hole di sisi $\mathrm{P}$.

\section{Mikrokontroler}

Mikrokontroller terdiri dari mikroprosesor, timer, counter, perangkat $\mathrm{I} / \mathrm{O}$, dan internal memory. Menurut Paulus Andi (2001:51) mikrokontroler termasuk perangkat yang sudah didesain dalam bentuk single chip ${ }^{8)}$. Pada dasarnya mikrokontroler mempunyai fungsi yang sama dengan mikroprosesor, yaitu untuk mengontrol kerja suatu sistem. Di dalam mikrokontroler terdapat CPU, ALU, PC, SP, dan register lain yang terdapat pada mikroprosesor, tetapi dengan penambahan perangkat-perangkat lain seperti ROM, RAM, PIO, SIO, counter, dan rangkaian clock.

Mikrokontroller didesain dengan instruksi-instruksi yang lebih luas dan 8 bit instruksi digunakan untuk membaca data instruksi dari internal memory ke ALU. Banyak instruksi yang digabung dengan pin-pin pada pada chip-nya. Pin tersebut adalah programmable pin yang mempunyai fungsi berbeda, tergantung pada kehendak programmer-nya. Sedangkan mikroprosesor didesain sangat fleksibel dan mempunyai banyak byte instruksi. Semua instruksi bekerja dalam sebuah konfigurasi perangkat keras yang membutuhkan banyak ruang memori dan perangkat I/O untuk dihubungkan ke alamat pin-pin bus data pada chip. Sedangkan besar aktifitas pada mikroprosesor bekerja dengan kode instruksi dan data pada atau dari memori luar ke CPU.

Mikrokontroler ATMega16 memiliki fitur yang lengkap (ADC internal, EEPROM internal, Timer/Counter, Watchdog Timer, PWM, Port I/O, komunikasi serial, Komparator, I2C,dll).

Berikut ini merupakan beberapa spesifikasi ATMega16:

1. Arsitektur RISC dengan throughput mencapai 16 MIPS pada frekuensi 16 Mhz.

2. Memiliki kapasitas flash memori 16Kbyte, EEPROM 512 Byte, dan SRAM 1Kbyte.

3. Saluran Port I/O sebanyak 32 buah, yaitu Port A, Port B, Port C, dan Port D.

4. CPU yang terdiri atas 32 buah register.

5. User interupsi internal dan eksternal.

6. Port USART sebagai komunikasi serial.

7. Konsumsi daya rendah (DC 5V).

8. Fitur peripheral, yang terdiri dari Tiga buah Timer/Counter, Real Time Counter dengan osilator tersendiri, channel PWM, channel,10-bit ADC, Byte-oriented Two-wire Serial Interface, Antarmuka SPI, Watchdog Timer dengan osilator internal, On-Chip Analog Comparator.

\section{Bluetooth}

Bluetooth merupakan sebuah teknologi komunikasi wireless yang beroperasi dalam pita frekuensi 2,4 GHz unlicensed ISM (Industrial, Scientific and Medical) dengan menggunakan sebuah frequency hopping tranceiver yang mampu menyediakan layanan komunikasi data dan suara secara real-time antara 
host-host bluetooth dengan jarak jangkauan layanan sekitar 10 meter. Bluetooth sendiri dapat berupa card yang bentuk dan fungsinya hampir sama dengan card yang digunakan untuk wireless local area network (WLAN) dimana menggunakan frekuensi radio standar IEEE 802.11, hanya saja pada bluetooth mempunyai jangkauan jarak layanan yang lebih pendek dan kemampuan transfer data yang lebih rendah.

Sistem bluetooth terdiri dari sebuah radio transceiver, baseband link Management dan Control, Baseband (processor core, SRAM, UART, PCM USB Interface), flash dan voice code. sebuah link manager. Baseband link controller menghubungkan perangkat keras radio ke baseband processing dan layer protokol fis ik. Link manager melakukan aktivitas-aktivitas protokol tingkat tinggi seperti me lakukan link setup, autentikasi dan konfigurasi. Secara umum blok fungsional pada sistem Bluetooth secara umum dapat dilihat pada gambar 8 dibawah ini

Gambar 8: Blok Fungsional Sistem Bluetooth

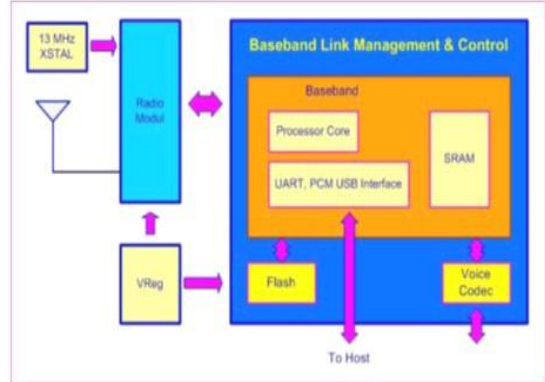

Sebuah perangkat yang memiliki teknologi wireless bluetooth akan mempunyai kemampuan untuk melakukan pertukaran informasi dengan jarak jangkauan sampai dengan 10 meter ( 30 feet), bahkan untuk daya kelas 1 bisa sampai pada jarak 100 meter. Sistem bluetooth menyediakan layanan komunikasi point to point maupun komunikasi point to multipoint.

Produk bluetooth dapat berupa PC card atau USB adapter yang dimasukkan ke dalam perangkat. Perangkat-perangkat yang dapat diintegerasikan dengan teknologi bluetooth antara lain : mobile PC, mobile phone, PDA (Personal Digital Assistant), headset, kamera digital, printer, router dan masih banyak peralatan lainnya. Aplikasi-aplikasi yang dapat disediakan oleh layanan bluetooth ini antara lain : $P C$ to PC file transfer, PC to PC file synch (notebook to desk top), PC to mobile phone, PC to PDA, wireless headset, LAN connection via ethernet access point dan sebagainya. Contoh modul aplikasi beberapa peralatan yang kemungkinan dapat menggunakan teknologi bluetooth dapat dilihat seperti Gambar 9 dibawah ini.

Gambar 9: Contoh aplikasi dari bluetooth

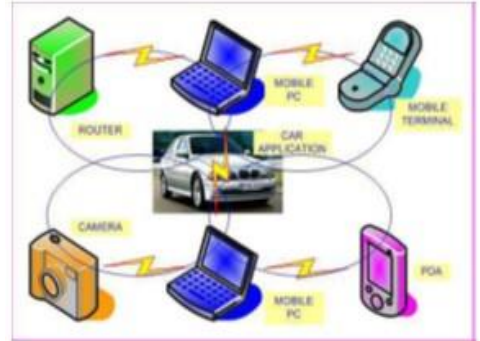

Di bawah ini merupakan beberapa keuntungan dari teknologi Bluetooth antara lain :

- Frekuensi band-nya terbagi kedalam hop-hop. Penyebaran spektrum ini digunakan untuk meloncat dari satu channel ke channel lainnya, yang dapat menambah tingkat keamanan pada lapisannya.

- Hingga 8 device/alat dapat saling dihubungkan dalam satu piconet.

- Sinyalnya dapat di-transmisikan melalui tembok dan briefcases hingga membatasi kebutuhan akan line-of-sight.

- Device tidak perlu dihubungkan satu sama lain, sebagai sinyal omnidirectional. 
- Sangat mendukung aplikasi synchronous dan asynchronous, sehingga memudahkan untuk mengimplementasikan device-device yang saling berbeda untuk berbagai macam layanan, misalnya seperti suara dan internet.

\section{Perencanaan dan Pembuatan Alat}

Berikut ini adalah gambaran blok diagram dari sistem kendali peralatan elektronim (radio) yang akan dibuat oleh penulis :

Gambar 10 Blok Diagram Sistem Kendali Pintu Gerbang

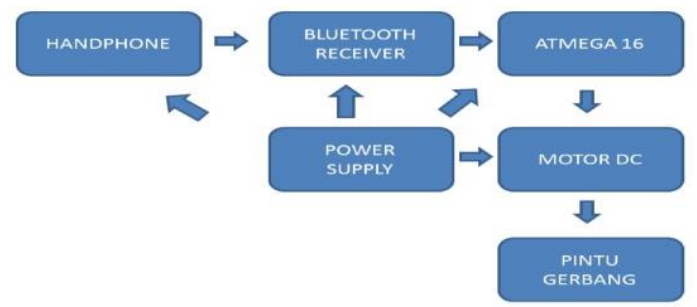

Dengan Handphone Melalui Bluetooth

(Sumber : Hasil Olahan Penulis)

Penjelasan blok diagram pada gambar 1 adalah sebagai berikut :

1. Handphone

Handphone yang digunakan adalah handphone Android yang sudah diinstal aplikasi gratis untuk membuat handphone tersebut bisa digunakan sebagai remot kontrol.

2. Bluetooth receiver

Bluetooth receiver yang digunakan adalah Bluetooth module keluaran bluesmirf tipe AUBTM22, hal ini dikarenakan tidak dimungkinkan membuat sendiri Bluetooth receiver.

3. Mikrokontroller

Mikrokontroller yang digunakan adalah tipe ATMEGA 16. Dimana memiliki 32 input dan output sinyal digital. Mikrokontroller menerima data inputan dari Bluetooth receiver yang berupa karakter, kemudian diproses dan outputannya akan dikirim ke dalam transistor untuk mendrive motor DC.

4. Motor DC

Motor DC digunakan untuk membuka atau menutup pintu gerbang dengan inputan berupa sinyal hight dari mikrokontroler, kemudian mendrive relay sehingga $12 \mathrm{Vdc}$ dapat memberikan supply ke motor yang akan menggerakkan motor.

\section{Rangkaian Keseluruhan}

Adapun rangkaian keseluruhan adalah seperti gambar berikut ini.

Gambar 11:Rangkaian Keseluruhan Sistem Kendali Pintu

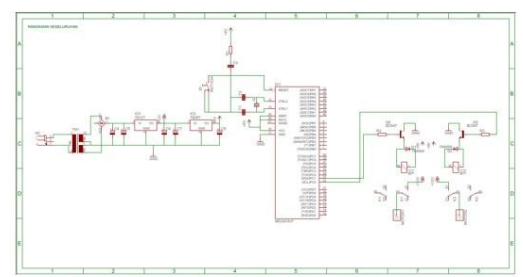

Gerbang Dengan Handphone Melalui Bluetooth

(Sumber : Hasil Olahan Penulis)

\section{Cara Kerja Perangkat keras}

Handphone akan memberikan perintah berupa data yaitu karakter "A0" atau "A9" yang merupakan deretan pulsa digital akan dikirim melalui Bluetooth handphone tersebut, kemudian data tersebut akan 
diterima oleh Bluetooth receiver yang terdapat dalam rangkaian yang selanjutnya akan diolah oleh mikrokontroller, data karakter yang sudah diolah oleh mikrokontroler akan membuat mikrokontroller mengeluarkan logika "1" diPORTC.0 atau diPORTC.1 yang kemudian akan menggerakkan relay-relay yang ada untuk membuat motor DC berputar yang kemudian akan membuka atau menutup pintu gerbang.

Gambar 12 : Flowchart Cara Kerja Peralatan

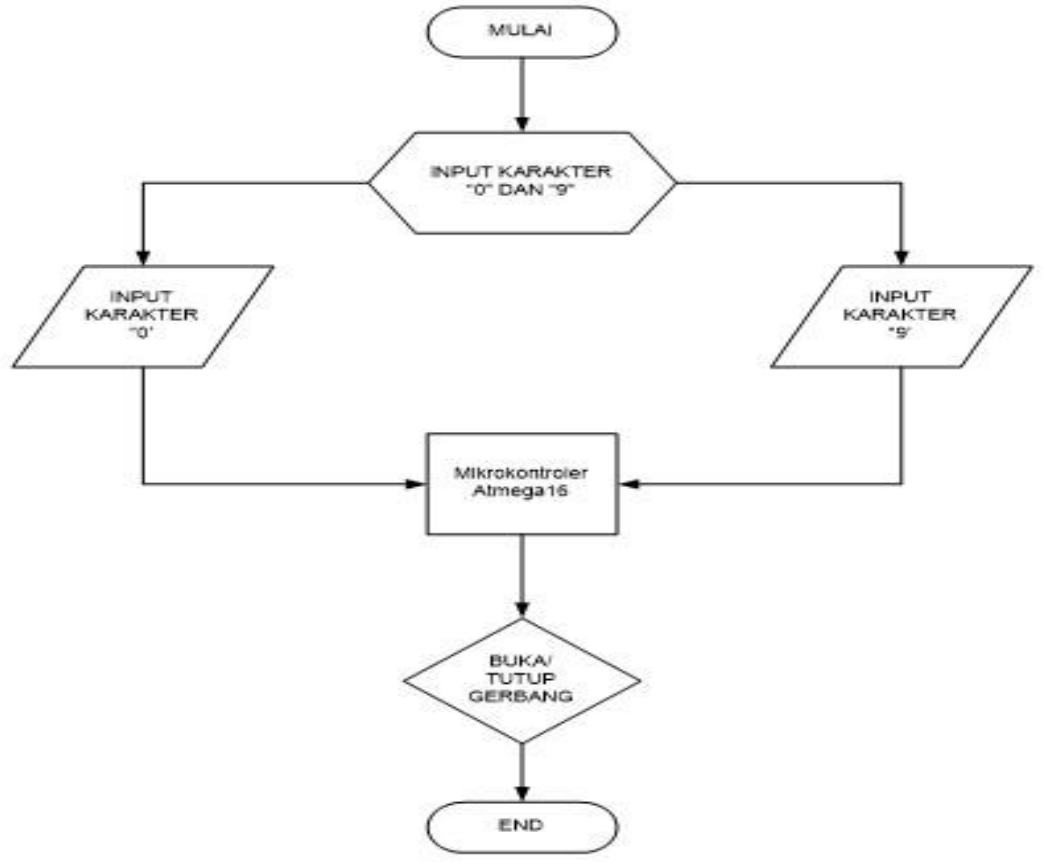

(Sumber : Hasil Olahan Penulis)

Berdasarkan flow chart seperti pada gambar 12 diatas Mikrokontroler mendapatkan inputan berupa karakter "A0" dan karakter "A9" yang kemudian akan diolah didalamnya sehingga bisa menggerakkan motor 1 atau motor 2 untuk membuka atau menutup pintu gerbang.

\section{Pembahas an Penelitian}

1. Analisa Rancangan Power Supply

Tegangan 220 Vac sebagai input trafo, kemudian output dari trafo adalah $14 \mathrm{Vac}$. Tegangan $14 \mathrm{Vac}$ ini kemudian menjadi input diode kiprog dan akan disearahkan menjadi $14 \mathrm{Vdc}$. Tegangan $14 \mathrm{Vdc}$ ini akan menjadi inputan IC regulator 7812 dan outputannya (12 Vdc) akan menjadi inputan bagi IC regulator 7805. Output dari IC regulator 7805 menjadi bias dari seluruh rangkaian utama dan rangkaian motor DC.

Tabel 2: Hasil Pengukuran Pada Rangkaian Power Supply

\begin{tabular}{|c|c|c|c|}
\hline & $\begin{array}{c}\text { Output } \\
\text { Trafo }\end{array}$ & $\begin{array}{c}\text { Output } \\
\text { IC 7805 }\end{array}$ & $\begin{array}{c}\text { Output } \\
\text { IC 7812 }\end{array}$ \\
\hline $\begin{array}{c}\text { Hasil } \\
\text { Pengukuran }\end{array}$ & 14 & 5 & 12 \\
\hline
\end{tabular}

(Sumber : Hasil Olahan Penulis)
Gambar 13: Rangkaian Power Supply

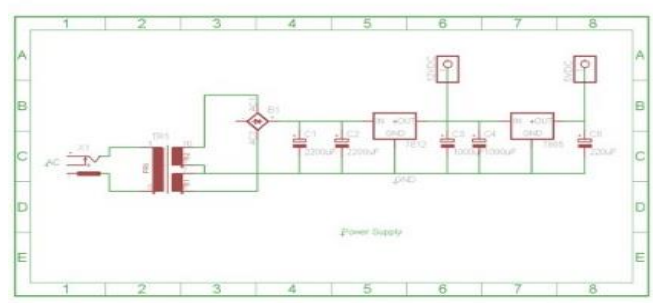

(Sumber : Hasil Olahan Penulis) 


\section{Minimum Sistem ATMEGA 16}

Minimum sistem adalah sebuah rangkaian minimal yang dibuat dengan tujuan agar mampu membuat sebuah mikrokontroler dapat bekerja sesuai dengan keperluannya. Pada rancangan ini penulis me mbuat rangkaian minimum sistem ATMEGA 16, karena penulis menggunakan ATMEGA 16 sebagai pemroses dan pengontrol dari seluruh rangkaian yang digunakan seperti digambar 5

\section{Gambar 14: Rangkaian Minsis ATMEGA 16}

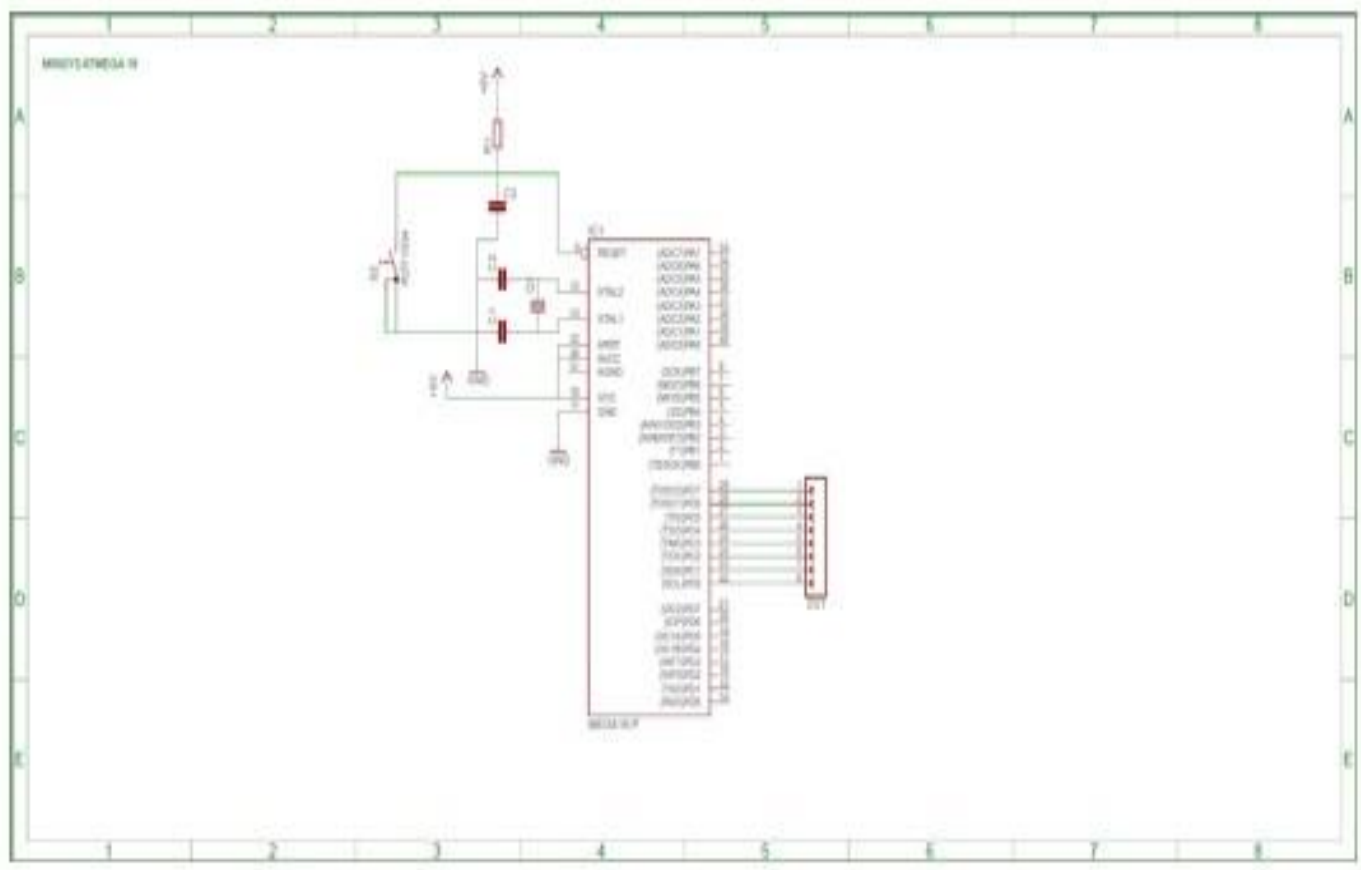

(Sumber : Hasil Olahan Penulis)

Tabel 3 :Hasil Pengukuran Pada Rangkaian Minsis Atmega 16

\begin{tabular}{|c|c|c|}
\hline No & Pengukuran Pada & Hasil Pengukuran \\
\hline 1. & Pin 10 dan 11 & $5 \mathrm{~V}$ \\
\hline 2. & PortA.0 - PortA.7 & $0 \mathrm{~V}$ \\
\hline 3. & PortB.0 - PortB.7 & $0 \mathrm{~V}$ \\
\hline 4. & PortC.0 - PortC.7 & $0 \mathrm{~V}$ \\
\hline 5. & PortD.0 - PortD.7 & $0 \mathrm{~V}$ \\
\hline
\end{tabular}

(Sumber : Hasil Olahan Penulis)

\section{Witching 12 Volt}

Untuk melakukan switching $12 \mathrm{Vdc}$ seperti pada gambar 6 dan tabe 3 tidak bisa dilakukan secara langsung melalui transistor akan tetapi harus melalui relay agar bisa menghubungkan sumber $12 \mathrm{Vdc}$ dengan motor DC. 
Gambar 15: Rangkaian Switching 12 Vdc

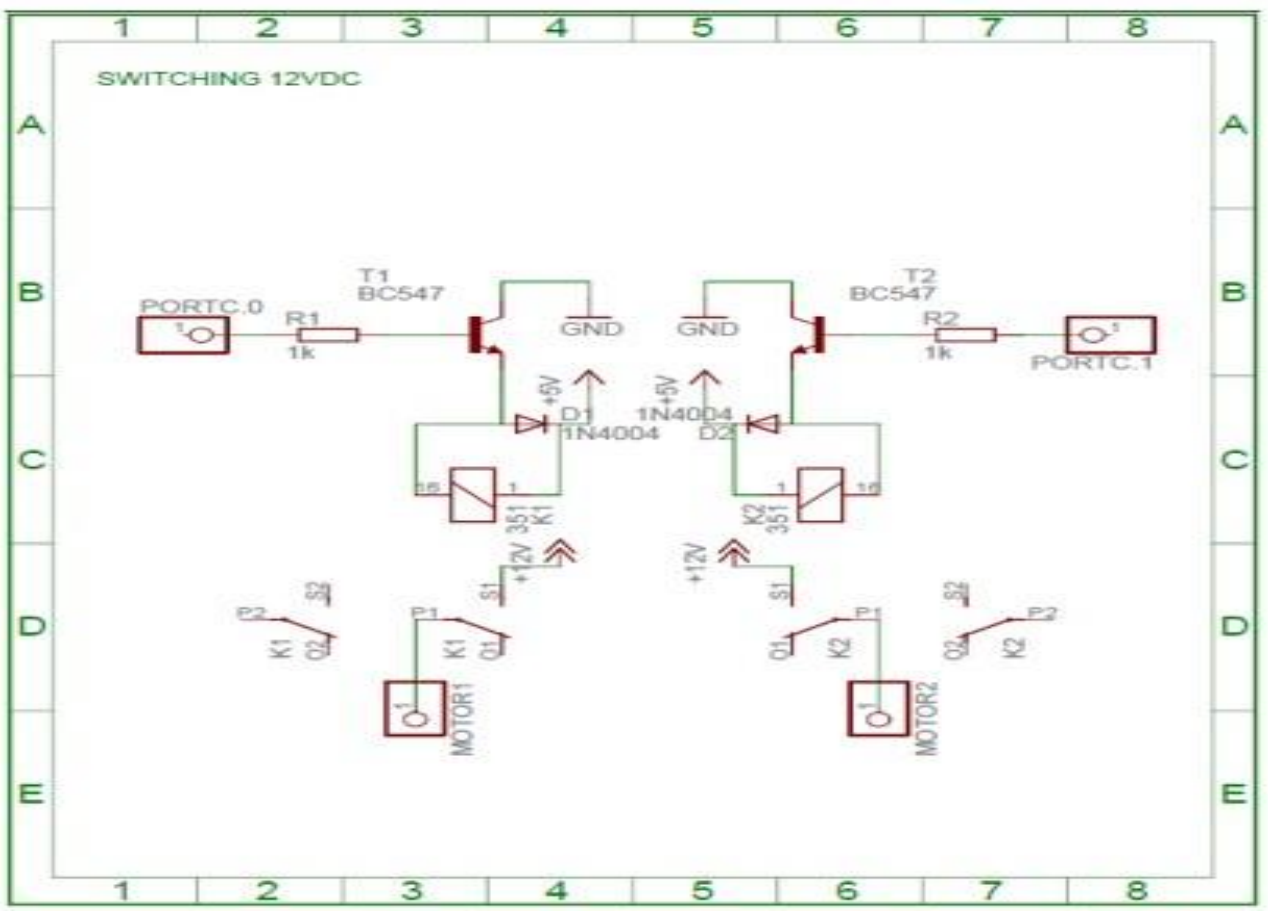

(Sumber : Hasil Olahan Penulis)

Tabel 4: Hasil Pengukuran Pada Rangkaian Switching 12 Vdc Terhadap Inputan Dari Mikrokontroler

\begin{tabular}{|c|c|c|c|c|c|}
\hline NO. & $\begin{array}{c}\text { Inputan Dari } \\
\text { Mikrokontroler }\end{array}$ & Relay 1 & Relay 2 & Motor 1 & Motor 2 \\
\hline 1. & PortC. $0=1$ & Energize & Collapse & Berputar & Tidak Berputar \\
\hline 2. & PortC. $0=0$ & Collapse & Collapse & Tidak Berputar & Tidak Berputar \\
\hline 3. & PortC. $1=1$ & Collapse & Energize & Tidak Berputar & Berputar \\
\hline 4. & PortC. $1=0$ & Collapse & Collapse & Tidak Berputar & Tidak Berputar \\
\hline
\end{tabular}

(Sumber : Hasil Olahan Penulis)

\section{Pengujian Perintah}

Untuk pengujian perintah ini penulis menggunakan 2 perintah, yaitu "A0" dan "A9" untuk menggerakkan motor 1 dan motor 2. Dimana motor 1 dan motor 2 digunakan sebagai pengatur buka tutup pintu gerbang. Karakter A0 digunakan untuk menggerakkan motor 1 yang berarti pintu gerbang akan bergerak ke kiri ( buka ) dan akan berhenti tepat pada saat pintu gerbang sudah membuka sepenuhnya ( 1 detik ) sedangkan Karakter A9 digunakan untuk menggerakkan motor 2 yang berarti pintu gerbang akan bergerak ke kanan ( tutup ) dan akan berhenti tepat pada saat pintu gerbang sudah menutup sepenuhnya ( 1 detik ).

\section{Pengujian Jarak Karakter Tanpa Halangan}

Untuk pengujian jarak ini penulis memasukkan 13 data jarak yang bervariasi untuk mewakili kondisi sesungguhnya. 
Tabel 5 : Hasil Pengujian Jarak Karakter A0 Tanpa Halangan

\begin{tabular}{|c|c|c|c|c|}
\hline NO. & Karakter Yang Dikirim & Jarak & Keadaan Motor 1 & Keadaan Motor 2 \\
\hline 1 & A0 & $1 \mathrm{~m}$ & Bergerak & Tidak Bergerak \\
\hline 2 & A0 & $2 \mathrm{~m}$ & Bergerak & Tidak Bergerak \\
\hline 3 & A0 & $3 \mathrm{~m}$ & Bergerak & Tidak Bergerak \\
\hline 4 & A0 & $4 \mathrm{~m}$ & Bergerak & Tidak Bergerak \\
\hline 5 & A0 & $5 \mathrm{~m}$ & Bergerak & Tidak Bergerak \\
\hline 6 & A0 & $6 \mathrm{~m}$ & Bergerak & Tidak Bergerak \\
\hline 7 & A0 & $7 \mathrm{~m}$ & Bergerak & Tidak Bergerak \\
\hline 8 & A0 & $8 \mathrm{~m}$ & Bergerak & Tidak Bergerak \\
\hline 9 & A0 & $9 \mathrm{~m}$ & Bergerak & Tidak Bergerak \\
\hline 10 & A0 & $10 \mathrm{~m}$ & Bergerak & Tidak Bergerak \\
\hline 11 & A0 & $11 \mathrm{~m}$ & Bergerak & Tidak Bergerak \\
\hline 12 & A0 & $12 \mathrm{~m}$ & Bergerak & Tidak Bergerak \\
\hline 13 & A0 & $13 \mathrm{~m}$ & Tidak Bergerak & Tidak Bergerak \\
\hline
\end{tabular}

(Sumber : Hasil Olahan Penulis)
Tabel 6: Pengujian Jarak Karakter A9 Tanpa Halangan

\begin{tabular}{|c|c|c|c|c|}
\hline NO & Karakter Yang Dikirim & Jarak & Keadaan Motor 1 & Keadaan Motor 2 \\
\hline 1 & A9 & $1 \mathrm{~m}$ & Tidak Bergerak & Bergerak \\
\hline 2 & A9 & $2 \mathrm{~m}$ & Tidak Bergerak & Bergerak \\
\hline 3 & A9 & $3 \mathrm{~m}$ & Tidak Bergerak & Bergerak \\
\hline 4 & A9 & $4 \mathrm{~m}$ & Tidak Bergerak & Bergerak \\
\hline 5 & A9 & $5 \mathrm{~m}$ & Tidak Bergerak & Bergerak \\
\hline 6 & A9 & $6 \mathrm{~m}$ & Tidak Bergerak & Bergerak \\
\hline 7 & A9 & $7 \mathrm{~m}$ & Tidak Bergerak & Bergerak \\
\hline 8 & A9 & $8 \mathrm{~m}$ & Tidak Bergerak & Bergerak \\
\hline 9 & A9 & $9 \mathrm{~m}$ & Tidak Bergerak & Bergerak \\
\hline 10 & A9 & $10 \mathrm{~m}$ & Tidak Bergerak & Bergerak \\
\hline 11 & A9 & $11 \mathrm{~m}$ & Tidak Bergerak & Bergerak \\
\hline 12 & A9 & $12 \mathrm{~m}$ & Tidak Bergerak & Bergerak \\
\hline 13 & A9 & $13 \mathrm{~m}$ & Tidak Bergerak & Tidak Bergerak \\
\hline & A & & & \\
\hline 1976 & & & & \\
\hline
\end{tabular}

(Sumber : Hasil Olahan Penulis)

6. Pengujian Jarak Karakter Dengan Halangan

Untuk pengujian jarak ini penulis memasukkan 9 data jarak yang bervariasi untuk mewakili kondisi sesungguhnya.

Tabel 7: Hasil Pengujian Jarak Karakter A0

Dengan Halangan

\begin{tabular}{|c|c|c|c|c|}
\hline NO & Karakter Yang Dikirim & Jarak & Keadaan Motor 1 & Keadaan Motor 2 \\
\hline 1 & A0 & $1 \mathrm{~m}$ & Bergerak & Tidak Bergerak \\
\hline 2 & A0 & $2 \mathrm{~m}$ & Bergerak & Tidak Bergerak \\
\hline 3 & A0 & $3 \mathrm{~m}$ & Bergerak & Tidak Bergerak \\
\hline 4 & A0 & $4 \mathrm{~m}$ & Bergerak & Tidak Bergerak \\
\hline 5 & A0 & $5 \mathrm{~m}$ & Bergerak & Tidak Bergerak \\
\hline 6 & A0 & $6 \mathrm{~m}$ & Bergerak & Tidak Bergerak \\
\hline 7 & A0 & $7 \mathrm{~m}$ & Bergerak & Tidak Bergerak \\
\hline 8 & A0 & $8 \mathrm{~m}$ & Bergerak & Tidak Bergerak \\
\hline 9 & A0 & $9 \mathrm{~m}$ & Tidak Bergerak & Tidak Bergerak \\
\hline
\end{tabular}

(Sumber : Hasil Olahan Penulis)

Tabel 8: Hasil Pengujian Jarak Karakter A9 Dengan Halangan

\begin{tabular}{|c|c|c|c|c|}
\hline NO & Karakter Yang Dikirim & Jarak & Keadaan Motor 1 & Keadaan Motor 2 \\
\hline 1 & A9 & $1 \mathrm{~m}$ & Bergerak & Tidak Bergerak \\
\hline 2 & A9 & $2 \mathrm{~m}$ & Bergerak & Tidak Bergerak \\
\hline 3 & A9 & $3 \mathrm{~m}$ & Bergerak & Tidak Bergerak \\
\hline 4 & A9 & $4 \mathrm{~m}$ & Bergerak & Tidak Bergerak \\
\hline 5 & A9 & $5 \mathrm{~m}$ & Bergerak & Tidak Bergerak \\
\hline 6 & A9 & $6 \mathrm{~m}$ & Bergerak & Tidak Bergerak \\
\hline 7 & A9 & $7 \mathrm{~m}$ & Bergerak & Tidak Bergerak \\
\hline 8 & A9 & $8 \mathrm{~m}$ & Bergerak & Tidak Bergerak \\
\hline 9 & A9 & $9 \mathrm{~m}$ & Tidak Bergerak & Tidak Bergerak \\
\hline
\end{tabular}

(Sumber : Hasil Olahan Penulis 
7. Pengujian Tegangan Port C.0 dan Port C.1 Terhadap Karakter A0 dan Karakter A9

Untuk pengujian tegangan port c.0 dan port c. 1 terhadap karakter "A0" dan karakter "A9" terlihat pada table 9 .

Tabel 9: Hasil Pengujian Tegangan Port C.0 dan Port C.1 Terhadap Karakter A0 dan A9

\begin{tabular}{|c|c|c|c|}
\hline NO & Karakter Yang Dikirim & Tegangan Port C.0 & Tegangan Port C.1 \\
\hline 1 & A0 & $0 \mathrm{~V}$ & $5 \mathrm{~V}$ \\
\hline 2 & A9 & $5 \mathrm{~V}$ & $0 \mathrm{~V}$ \\
\hline
\end{tabular}

(Sumber : Hasil Olahan Penulis)

\section{Analisa}

Dari hasil pengujian yang dilakukan untuk jarak pengiriman data karakter lebih dari $12 \mathrm{~m}$ adalah tidak terkirim, dan batas maksimal jarak pengiriman data jika terdapat penghalang adalah $8 \mathrm{~m}$. Hal ini disebabkan oleh spesifikasi dari Bluetooth pengirim yaitu Bluetooth yang ada dihandphone. Bluetooth dihandphone hanya memiliki spesifikasi jarak pengiriman data sampai dengan $12 \mathrm{~m}$ tanpa halangan dan kekuatan powernyah hanya bisa menembus penghalangan sampai dengan jarak $8 \mathrm{~m}$.

\section{Kesimpulan dan Keterbatasan}

Berdasarkan hasil analis is data yang telah dilakukan maka kesimpulan dari penelitian ini adalah bahwa Modul Bluetooth serial dapat diaplikasikan sebagai media transmisi data pengganti kabel RS 232, Mikrokontroler dapat melakukan pengolahan data informasi dari Bluetooth dan dapat juga digunakan sebagai pengontrol lama putaran motor, Dengan adanya rancangan ini dapat mengatasi masalah yang ditimbulkan oleh remote kontrol yang menggunakan infra merah sebagai media transmisinya.

\section{Keterbatasan}

Berdasarkan hasil penelitian, penelitian ini memiliki keterbatasan diantaranya yaitu waktu pada saat penelitian, sehingga peneliti tidak mempunyai waktu yang cukup untuk penelitian, Jadi disarankan peneliti selanjutnya di harapkan untuk lebih memanfaatkan waktu maupun bisa membagi waktu sebaik mungkin untuk penelitian.

\section{Daftar Pustaka}

Fauzi,M. K. A., 2014, Pemanfaatan Komunikasi Bluetooth Untuk Buka Tutup Gorden, Tugas Akhir, D3 Teknik Elektro, Sekolah Vokasi, UGM, Yogyakarta.

Febriansyah, D., 2015, Alat Kendali Lampu Rumah Menggunakan Bluetotoh Berbasis Android. Jurnal, STMIK Pal ComTech, Palembang

Malvino dan Gunawan ; Prinsip-Prinsip Elektronika, Erlangga, Jakarta, 1978.

Pratama, F. N., 2010, Smart House Berbasis Mikrokontroller 89S51, Tugas Akhir, D3 Ilmu Komputer, Universitas Sebelas Maret, Surakarta.

Yehuda, 2013, Purwarupa Sistem rumah cerdas Berbasis Arduino Uno Yang Dikendalikan Dengan Smartphone Android, Tugas Akhir, Elektronika dan Instrumentasi, UGM, Yogyakarta. 